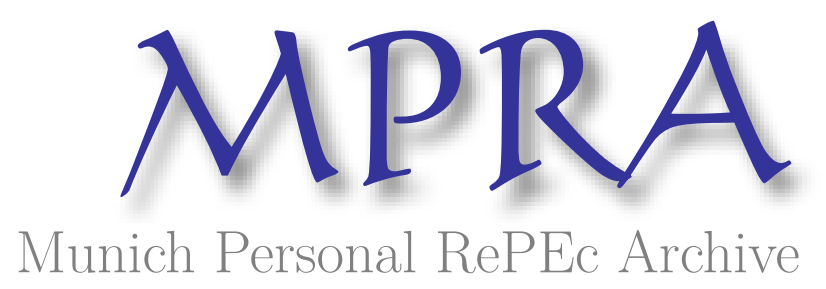

\title{
Redistribution and Reelection under Proportional Representation: The Postwar Italian Chamber of Deputies
}

Golden, Miriam and Picci, Lucio

University of California, Los Angeles, University of Bologna

25 March 2011

Online at https://mpra.ub.uni-muenchen.de/29956/

MPRA Paper No. 29956, posted 07 Apr 2011 08:00 UTC 


\title{
Redistribution and Reelection under Proportional Representation: The Postwar Italian Chamber of Deputies
}

\author{
Miriam Golden \\ Department of Political Science \\ Box 951472 \\ University of California at Los Angeles, CA 90095 \\ golden@ucla.edu \\ and \\ Lucio Picci \\ Department of Economics \\ University of Bologna \\ Strada Maggiore 45, 40125 Bologna \\ lucio.picci@unibo.it
}

This version: 25 March 2011 


\section{ACKNOWLEDGEMENTS}

The research reported here was supported by the Academic Senate of the University of California at Los Angeles, the National Science Foundation SES-0074860, and a Russell Sage

Foundation Fellowship. Earlier versions of this paper were presented at a Workshop on

Distributive Politics, University of California at San Diego, April 18-29, 2008, at the 2008

Annual Meetings of the American Political Science Association, Boston, August 28-September

1, and at the $18^{\text {th }}$ Workshop in Political Economy, Silvaplana, July 25-29, 2009. 


\begin{abstract}
We study incumbency advantage and the electoral returns to pork and patronage over ten legislative periods from 1948 to 1992 for two political parties — the Christian Democrats (DC) and the Italian Socialist Party (PSI) — in Italy's lower house of representatives, the Chamber of Deputies. Adapting a regression discontinuity design to Italy's open-list system of proportional representation, we show that parliament comprised two groups: a small elite, whose members enjoyed an incumbency advantage, and the average deputy, who benefitted from no such incumbency advantage. Elite legislators affiliated with Italy's two main parties of government received significantly more preference votes when pork and patronage were steered to their districts, although the effect is small. We interpret this to indicate that their incumbency advantage was linked to their ability to claim credit for these allocations. We also show that the two parties won more list votes when districts received more resources and that when districts received more resources, the abilities of these parties to persuade their electors to use preference votes improved. This form of electoral mobilization, in turn, enlarged the number of ministerial positions secured by the district. Our analysis depicts a political environment severely segmented between a small, powerful elite group of deputies and backbenchers.
\end{abstract}


Legislator turnover is significantly greater under proportional representation (PR) than in singlemember district settings (SMD) in stable democratic political systems (Matland and Studlar 2004). But if the principal objective of an elected official is to secure reelection, we would expect successful politicians in PR environments to anticipate this and to erect protections against loss of office. Is this the case and what kinds of protections are effective?

In this paper, we enlarge our empirical understanding of how politicians manipulate the political environment to gain reelection under PR. We study lower house reelection over four decades in Italy, a country whose comparative incumbency return rate is estimated to be 65 percent (Matland and Studlar 2004, p. 93, table 1), exactly the average for the industrialized democracies. We adapt a regression discontinuity design to the context of open-list proportional representation to assess whether Italian deputies associated with two political parties - the dominant Christian Democrats (DC) and the smaller Italian Socialist Party (PSI) — in Italy's lower house of representatives, the Chamber of Deputies, enjoy an incumbency advantage over eleven legislative periods between 1948 and 1992. We then study whether such an advantage is associated with the distribution of pork and patronage. Specifically, we examine the electoral returns to government spending on infrastructure construction, a notorious marker of pork barrel politics, and on the distribution of disability pensions, well known in Italy for being allocated on the basis of political rather than medical criteria. We study three types of electoral outcomes: the number of votes received by individual DC and PSI candidates, the share of votes received by the two parties, and the ratio between the two. For reasons we explain in detail, in the context in which we work the latter captures the ability of politicians to induce voters to use their individual preference votes, which we argue served as a marker of the size of the politician's clientele. 
To encapsulate our findings, they are that the average Christian Democratic and Socialist legislator in postwar Italy experienced no incumbency advantage. Instead, most were either not relisted or, if they were relisted, failed to achieve reelection after a single term in office. However, a small elite in each party successfully retained legislative office for multiple terms. These incumbents appear to have received political credit from voters for the allocation of government resources. The allocation of pork and patronage simultaneously shifted votes from other parties to their party and induced voters to use their individual preference votes in the first place. These successful elite legislators targeted their districts with distributive goods in order to improve their own probabilities of reelection, to bolster the number of votes going to their party, and, finally, to persuade voters to provide evidence that the politician controlled a large clientele. However, the effects that we detect, while statistically significant, are small in magnitude. For example, an increase of 10 percent in disability pensions in an electoral district adds only 0.7 percent to the number of votes received by the Christian Democratic Party in that district, and the same increase in public investments adds roughly the same amount of votes to the Socialist Party's votes. When we detect an effect of distributive goods on preference votes for candidates listed by these two parties, a 10 percent increase in resources accruing to the district translates at most to an increase in preference votes that is slightly below 1 percent.

Our paper is organized into five main sections. In the first, we briefly review relevant literatures on incumbency advantage and on distributive politics and discuss how to extend them from single-member district settings to multimember proportional representation. In a second section, we describe some features of the postwar Italian context and of our data. Next we report the results of baseline regression discontinuity analyses of incumbency effects. A fourth section 
of the paper presents results of estimations of the impact of distributive politics on incumbency, vote getting by parties, and preference vote utilization. A final section concludes.

\section{Conceptualizing Incumbency Effects under PR}

In single member district settings (SMD), it is straightforward to study legislators and parties because within each district the two are effectively identical. Multimember legislative districts are more complicated political environments, however, and there is no established procedure for estimating the relationship between an individual incumbent, any natural electoral advantage she may enjoy, and the swings in partisan preferences that affect the electorate. A multimember PR setting provides special analytic challenges to isolating and identifying the impact of incumbency advantage. Any incumbency advantage enjoyed by individual legislators must be distinguished from electoral advantages accruing to parties of government and also from advantages enjoyed by fellow legislative representatives elected in the same district, especially representatives serving in the same party. Prior attempts (including, Ames 1995; also Crisp and Desposato 2004) to characterize and estimate the size of incumbency effects under proportional representation are rare. The literature on incumbency effects under SMD includes some studies on multiparty SMD settings, such as the U.S. Senate (Cox and Morgenstern 1995) and the British House of Commons (Katz and King 1999), but the techniques of analysis used in these settings do not extend seamlessly to multiparty multimember settings. Finally, the development of regression discontinuity designs to estimate incumbency advantage, first advanced to study elections to the U.S. House of Representatives (Lee 2008), offers a new and more robust technique that casts doubt on the results of earlier studies that necessarily employed other analytic tools. We are not aware of prior studies prior using a regression discontinuity design to 
estimate incumbency effects under multiparty and multimember open-list PR but the introduction of such methods calls for extension to those environments.

The main reason that incumbency effects under PR have not been studied much is thus probably because of inherent conceptual difficulties. Another reason may lie with the tendency to mischaracterize these systems as ones in which parties rather than candidates contest elections. This is true, however, only for closed-list systems in which candidates are elected to the legislature solely by virtue of their position on a party-ordered list. Most PR systems allow voters a preference vote for individual candidates (Katz 1986), thereby altering the order by which candidates are elected off of party-ordered ballot lists. This makes it interesting as well as important to investigate whether individual legislators in the ostensibly strong party environments characteristic of PR deploy resources strategically in efforts to attract votes and secure reelection. Indeed, to the extent that "the personal vote" is salient even in multimember settings (Carey and Shugart 1995), legislators have incentives to distinguish themselves from their rivals within their own party. And to the extent that incumbency provides less of an electoral advantage than in SMD environments, legislators have even more reason to insulate themselves from electoral vulnerability. Whether they succeed in doing so is an empirical question. Since a defining trait of successful politicians is their demonstrable adroitness in strategically amending their institutional environment to retain office, it may well be the case that some legislators in multimember settings have devised ways to credit claim, thereby enhancing their reelection probabilities.

To estimate incumbency advantage under PR, we first identify the relevant political actors and characterize their preferences. We study candidates for legislative office and the political parties that organize electoral competition. We discuss each in turn. 


\section{Preferences of (Prospective) Members of Parliament}

We first characterize the preferences of individual legislators. Politicians are typically characterized as office seeking. Hence, their first priority is to enter parliament, to remain there, and, in the context of strong political parties, to advance in the party hierarchy because this in turn reinforces reelection probabilities. In an open-list PR setting, both reelection and resources to advance a political career depend on amassing preference (that is, individual) votes. We thus operationalize the goal of the individual legislator as the number of (preference) votes he receives.

Compare this to the situation of a legislator in an SMD system, where the legislator's main objective is also to be (re-)elected. In order to achieve reelection, a majority of votes is both necessary and sufficient. In competition between two candidates, being slightly or vastly above the 50 percent mark essentially makes no difference. Under PR, by contrast, candidates seek not only a seat but also to maximize the number of preference votes. There are at least two specific reasons why this is true. The first, as we document below, is that deputies with more preference votes have a higher probability of being reselected in the next period, thus fending off the risk of being retired by the party. More preference votes in the current period not only win the seat but also protect the legislator from being forced off the party list in the subsequent period. A second reason for seeking to maximize preference votes is that deputies with more preference votes hold more important positions within the party and thereby improve their prospects of becoming an undersecretary or a minister (see the data reported in Table 2 in Golden and Picci, 2008). For both reasons, the incentive to maximize preference votes would be strong even if an incumbent were virtually assured of being elected (which the average incumbent under PR is not) because 
remaining in parliament and amassing political clout more generally depend on the number of preference votes received. ${ }^{1}$

\section{Credit Claiming for the Distribution of Resources}

Claiming credit for constituency service and for the distribution of government resources are inherently more difficult in multimember than single-member districts (Lancaster 1986). This "appropriability" problem within the district - it may not be clear to electors whom among several legislators is responsible for benefits received in the district - may make it difficult for incumbents to generate preference votes.

Credit claiming for benefits such as pork barrel and patronage resources is relatively easy in a SMD system, by contrast. Although outcomes may be affected by exogenous shocks, so that electors are uncertain whether a given outcome is due to deliberate political action or to mere luck, the identity of the legislator responsible for securing the resources is not uncertain. All expenditures benefiting a given district that derive from a bill approved by the legislature can be linked directly to the sole congressional representative elected from that district. The representative thereby finds it fairly straightforward to take credit for any pork barrel expenditures that she manages to secure.

In proportional representation with multimember districts, by contrast, the resources that go to the district are affected not only by idiosyncratic shocks but also by the collective activity of multiple legislators. In such a setting, credit claiming by an individual deputy may be easier for localized expenditures that benefit an area of the district corresponding to the "turf" of one or only a few representatives, or for outlays — such as pensions — that target particular persons, since the latter would be typical instruments of personalistic exchanges within a patron-client 
relationship. ${ }^{2}$ Credit claiming may also be easier in situations where a district elects a "superstar" deputy known to have particular clout in the capital. If the deputy is a minister, he may be able to funnel resources that, by originating from his ministry, almost literally carry his signature. Appropriability — the capability of a deputy to be recognized as responsible for resources accruing to her district — is bound to be more difficult to secure in other cases, and in particular for expenditures that benefit the district in a less localized fashion. To make the problem more complex, the problem of appropriability also occurs between parties, given that multiparty PR systems are typically governed by coalitions of political parties. ${ }^{3}$

Consider two extremes, corresponding to different levels of appropriability. At one end of the spectrum, elected deputies successfully credit claim for their successes — possibly because the expenditures are well targeted to their turfs or go to known and clearly demarcated clienteles — such that the electorate knows who is to be thanked, say, for a new road or blamed for shirking in the corridors of Rome. At the other extreme, the electorate, witnessing the delivery of pork, may be able to identify only a whole political party or possibly even the ruling government coalition as responsible, and lacks the ability to assess the contribution of individual legislators to the final outcome. ${ }^{4}$

Legislators face diverging incentives in these two polar situations. The incentive to expend effort in securing pork barrel resources is greater if the results are more easily politically appropriable. If, alternatively, credit claiming is difficult, the effort of the individual deputy is a kind of public good that contributes to an advantage shared by multiple deputies representing the same electoral district. In this case, we would expect that legislators might not invest as much effort in securing pork barrel resources (Lancaster 1986). So even given identical preferences, the strategies of deputies regarding distributive politics may differ depending on the extent to 
which deputies are able individually to credit claim. Below, we model empirically possible factors that allow individual deputies to credit claim with voters.

We now complicate these considerations by incorporating relations between inter-party competition (for party votes) and intra-party competition (for preference votes).

\section{Parties and Politicians}

The preferences of parties are to increase the total number of list votes they receive. In principle, a party in a PR system does not care about the geographic origin of its list votes, since under PR all votes contribute equally to the total number of elected legislators for the party. Under open-list PR, there is no such thing as a marginal or swing district or seat and all votes matter equally to the party in the number of seats it gains in the legislature. We thus operationalize the goal of the party as the number of (list) votes it receives.

Thus far, we have argued that the party would like to maximize the total number of votes or, what is the same thing in a PR setting, the size of its delegation in parliament, since this is the main determinant of its relative weight in the ruling coalition and its overall political fortune. Hence, the main concern of the party is to maximize list votes. We have already explained why the individual legislator, by contrast, is interested in maximizing the number of preference votes that are cast — in the first instance, for himself.

Individual legislators, however, while competing with other candidates on the party list in their home districts, also share interests with them. In order to increase the size of the district's electoral delegation in parliament and to empower the district's legislators in the party's national hierarchy, thereby making it more likely that deputies will successfully secure more pork and patronage resources, the individual legislator has an incentive to increase the overall number of 
preference votes cast in his district. Legislators seek to persuade voters to cast preference votes for them but the effect of the local party networks in which they are embedded is to mobilize the party's electorate to use preference votes for other candidates in the party as well.

This incentive of the individual legislator to maximize preference votes, conditional on the number of list votes to the party, is present only insofar as the value of preference votes in advancing the legislator's career is not adjusted downwards in districts where there is a higher propensity to cast preference votes. That is, in districts where relatively many preference votes are used by voters, the votes of an individual deputy may be partially discounted in allocating him resources within the party because the party leadership may take the propensity to use preference votes for granted. The individual deputy may not receive full credit within the party for the preference votes that he accrues.

\section{Inter-Party and Intra-Party Competition}

Because an increase in list votes does not translate automatically into an increase in preference votes and an increase in preference votes does not necessarily translate into an increase in list votes, the strategies that legislators and their parties deploy in their efforts to maximize preference and list votes are not entirely congruent. We explain the conditions under which their strategies result in complementary versus contradictory electoral outcomes.

New preference votes may come from two sources. At one extreme, all new preference votes may also be new votes for the party; that is, the deputy who is successful in distributive politics manages to "steal" votes from competing parties. In this case, both the deputy and her party have convergent interests in obtaining preference votes, since doing so increases the electoral support of the individual legislator and the party to the same extent. This is the logic that underlies multi-tiered as opposed to solely local "political machines," where the personal 
interests of local politicians add up to those of the local party branches and these in turn smoothly aggregate to coincide with the overall interests of the higher-level machine, the national party.

At the opposite end of the spectrum, electors may be frozen in their party choices because of the presence of strong ideological commitments or ethnic ties, for instance. In this case, two polar subcases are possible. In one of them, the ratio between voters within each party using preference votes and voters who only use their party vote is fixed. We may imagine that there are "literate" party voters who are able and willing to write out the names of prospective individual legislators on the ballot and that there are "illiterate" voters who can only put a cross next to the party symbol and hence are unable to use their preference votes. In this case, deputies who credit claim for the resources that they secure for the district are playing a zero-sum game against other deputies of the same party: everyone tries to outdo her fellows in the district in order to grab part of a fixed total number of preference votes. This induces intense intra-party competition at the district level but does not give the party any incentive to secure resources for the district because additional resources do not translate into additional preference votes. ${ }^{5}$

A second possible subcase occurs when, although voters may be frozen in their ideological commitment to their party, good deeds by individual legislators may convince voters who previously only cast a party vote to use some of their preference votes — that is, illiterate voters may become literate. Unlike the previous case, the interaction among candidates is no longer zero-sum, at least up to a saturation point that corresponds to the level where voters of the party are all "literate," that is, where all voters use all their preference votes. From the point of view of the party, however, the struggle to obtain distributive resources is zero-sum across districts and the party has no particular interest in increasing the number of preference votes cast. 
This discussion of the possible divergence between legislators and their parties in openlist PR suggests they may have different incentives in distributing political resources to amass votes. Parties have the incentive to increase list (party) votes, whereas legislators have the incentive to increase individual (preference) votes. Directing concentrated benefits to electoral districts in principle may do both. Hence, both parties and politicians may have incentives to pork barrel. However, to the extent that individual deputies experience difficulties in credit claiming, their incentives may diverge from those of their parties.

The complexity of multimember PR, in which legislators and parties are likely to enjoy only partially convergent interests, therefore militates against the development of a general incumbency advantage for legislators. Indeed, for the reasons outlined above, it is not surprising that legislator turnover is greater in PR than SMD settings, as has been found to be the case (Matland and Studlar 2004). This suggests that skilled politicians, as opposed to their less skilled counterparts, will manipulate the environment to insulate themselves against removal from office. Under open-list PR, the goal of developing an orderly and predictable political environment suggests that some legislators will enjoy a significantly greater incumbency advantage than others.

\section{The Context and Data}

Our dataset is large and rich. In addition to detailed information on the careers of all legislators (and candidates from two parties) in Italy's postwar Chamber of Deputies through 1994, we have annual information on public infrastructure investments and disability pensions, two important types of distributive allocations, disaggregated by year and by electoral district. (Details on this data are provided later.) We have information on various characteristics of the 
630 individual deputies who sat in each legislature as well as on socioeconomic characteristics of Italy's 32 electoral districts. ${ }^{6}$

Our analysis considers the two most important political parties of government during the period under consideration: Christian Democracy, which served in power for the entire period, and the Italian Socialist Party, which ran on a joint list with the Italian Communist Party (PCI) in the first postwar elections of 1948 but then moved progressively further from the PCI until, in 1963, it entered a government coalition with the DC, where it remained for most of the ensuing period covered in our study. Our analysis does not include the other small parties that frequently were part of the governing coalition because we do not have information on all of their candidates. We exclude from analysis the country's major opposition party, the PCI, for the same reason. However, even investigating only the DC and the PSI allows us to study 48 percent of all legislators who sat in the Chamber of Deputies between 1948 and 1992.

Our study treats candidates to Italy's lower house, the Chamber of Deputies, but not the Senate because of an absence of complete data on Senators. In what follows, we use the term "legislator" to refer to deputies and also to candidates who might have lost while running for the Chamber. Finally we omit from analysis the elections held in 1992 for the Eleventh Legislature because the number of preference votes that voters could use was reduced to one in these elections. Our analysis thereby spans the ten legislative periods during the so-called "First Republic" between 1948 and 1992. During that period, electors could vote for a party and use up to three (or in larger electoral districts, four) preference votes for any of the individuals whose names appeared on the party list. ${ }^{7}$ In the open-list PR system in operation until 1994, electoral choices thus had three separate dimensions: whether to vote at all, ${ }^{8}$ the party to vote for and, 
given that, whether to cast preference votes for any individuals on that party's list. We examine these electoral choices separately.

\section{Empirical Analysis of Incumbency: Baseline Models}

We begin the empirical analysis with non-parametric evidence to assess the presence of an incumbency advantage. We then consider the reselection of incumbents for the next election.

\section{A Regression Discontinuity Approach}

A simple and commonly used way to estimate the presence of any incumbency advantage is with a regression discontinuity approach. This has been used in recent studies in SMD contexts (Lee 2008; Miguel and Zaidi 2003; Linden 2004). The intuition behind such an approach is simple. Candidates who barely win an election (in an SMD context, candidates who receive a fraction of votes just above the 50 percent mark) may be assumed to be equal, in terms of quality and other relevant unobservable characteristics, to candidates who barely lose (that is, who receive slightly less than 50 percent of the vote). For the subset of these candidates who run again in the next election, however, an important difference exists: those who barely lost in the previous election are now challengers rather than incumbents. Those who barely won, having served in the previous legislature, enjoy whatever incumbency advantage may exist. The size of the incumbency effect may be estimated by observing the (positive) difference in the fraction of votes between candidates who barely won in the previous election and candidates who barely lost. If an incumbency advantage is present, we observe a positive discontinuity in the percentages of votes around the 50 percent mark (Imbens and Lemieux 2007 and Lee and Lemieux 2010 provide general treatments of the technique). An incumbency disadvantage, conversely, is indicated by a negative discontinuity. In the United States, for instance, Lee 
estimates being an incumbent provides Democratic Party candidates with a 45 percent greater probability of winning, during elections between 1946 and 1998 (2008, p. 686). The results have a straightforward causal interpretation; that is, being based on an estimate of the difference in outcome close to the cutoff point, it is deemed to be due to an incumbency effect alone rather than to other characteristics, such as the skill of the candidates.

Within a PR system such as the one that we consider, the analogue to the 50 percent fraction of votes is, within each district and election, the minimum number of preference votes that allows a candidate to be elected. We operationalize this for each party as the difference between the number of preference votes obtained by the most voted unsuccessful candidate (the biggest loser) and the number of votes obtained by the least voted candidate on the party list who was elected (the lowest ranking winner). We take this difference as an approximation of the minimum number of additional preference votes needed to be elected. We define the variable successratio as the ratio of the number of preference votes obtained by each candidate and the minimum number of votes required to be elected, as just defined. This variable is smaller (bigger) than 1 for unelected (elected) candidates.

In Figures 1A and 1B, we graphically depict the difference in the variable successratio between each two subsequent elections for candidates running on the lists of the DC and the PSI using data from the First to the Tenth Legislatures. Each observation is a single candidate who ran again after serving only one term or after having lost in the previous election. If an incumbency effect is present, we would expect the difference of votes between subsequent elections to be significantly higher for the candidates who are incumbents (that is, for whom the measure on the x-axis is greater than 1) than for their unelected competitors. In other words, in contests between incumbents and challengers who are otherwise indistinguishable, an 
incumbency advantage is present if the incumbent receives a "surplus" number of preference votes. ${ }^{9}$ Figures $1 \mathrm{~A}$ and $1 \mathrm{~B}$ also show $7^{\text {th }}$ order polynomials fitted (with OLS) separately for losing and for winning candidates for the DC and for the PSI. The distance between the fitted lines where they meet at the vertical cut-off line is the estimated incumbency effect.

\section{Figures $1 \mathrm{~A}$ and $1 \mathrm{~B}$ about here}

Visual inspection of the data depicted in Figures 1A and 1B indicates the lack of any incumbency effect, a result confirmed by formal testing. ${ }^{10}$ This way of viewing the data documents that for the two major parties of government, incumbents with one term of seniority had no advantage over their unelected but otherwise indistinguishable competitors. Incumbency by itself appears to offer no electoral advantage in postwar Italy. Given this, incumbents would have had stronger incentives than elsewhere to undertake activities that would confer electoral advantage to escape this frightening and disorderly electoral world. Even if the average incumbent was not successful in achieving this, some incumbents may have been.

\section{The Reselection of Candidates}

In the above section we found no evidence of an incumbency advantage for candidates with one term of legislative tenure conditional on being included on the party list for the next election. In this section we document the presence of a negative incumbency effect that is the result of the power of the party in candidate selection. We show that for Christian Democratic and Socialist incumbents any number of terms of legislative tenure greater than 1 negatively affects the probability of being reselected.

In the attempt to hold on to his parliamentary office, an incumbent legislator confronts two distinct obstacles. First, he must be reselected by his party; included, that is, among its 
candidates on the party list. Within a PR system such as the Italian, it was the party that decided whom to include on the list of candidates. ${ }^{11}$ Conditional on having achieved this initial goal, the deputy then had to receive enough preference votes to be reelected.

Table 1 shows the distributions of terms of tenure for postwar DC and PSI legislators. In both parties, more than half of the deputies ever elected to the Chamber in the decades we study serve no more than two terms. If we compare this with what we know about the U.S. Congress, Italian deputies stay in parliament significantly fewer terms. In the United States between 1947 and 1993, congressional representatives serve an average of five terms (Diermeier, Keane, and Merlo 2005, p. 367n51) compared with an average of 2.31 terms for the almost identical period for the Italian deputies in our dataset (slightly higher, 2.73 , for the DC, and equal to 2.39 for the PSI). In fact, political parties have an incentive to exclude deputies after several legislatures of service because these deputies were eligible to receive government pensions and could work for the party machine for free at that point. In an analysis of the occupations of a representative sample of deputies leaving the Chamber between 1947 and 2007, one study reports that 54 percent of former deputies take permanent jobs within their party organization upon leaving elected office (Merlo, et al. 2009, p. 42). This might contribute to the results that we observe in Table 1: once a legislator has sufficient seniority to obtain a parliamentary pension, the party has an incentive to retire him.

\section{Table 1 about here}

There were exceptions, particularly in the DC and to a lesser extent in the PSI. A small number of highly skilled deputies became almost permanent fixtures in parliament. In the DC, for instance, roughly 40 persons (less than 4 percent of the 997 individuals who held seats in the Chamber over the 11 legislative periods of the First Republic) served seven or more terms. This 
is distinctly at odds with the widespread impression (in Italy, at least) of a permanent political elite in office for the entire postwar era. Rather, career prospects could roughly take one of two paths. The incumbent could be a "normal" deputy who would not expect to be reselected after one or two legislative terms, or he could be a "superstar" who would expect to be included almost automatically on the list for subsequent elections and who had a good chance of eventually securing a ministerial position. The latter individuals, although politically prominent, were few in number.

In order to analyze the determinants of the party's decision to retain incumbents as candidates in future elections, we next run a probit model where the decision to reselect an incumbent legislator in the next election is explained by a series of district or individual characteristics. Among district characteristics, we include the difference in electoral performance by the party in the district with respect to the national average, since it could be that the party rewards deputies in districts that performed well with a higher probability of being retained as candidates. To operationalize this, we define the variable $D D C \_$dif as the difference in the percentage change of votes over the previous election in the district compared to the same difference computed at the national level. A positive value indicates that the DC did relatively better in the district relative to the national average. We define the variable DPSI_dif in equivalent fashion for the PSI. We also include legislature fixed effects, to control for any time idiosyncratic effect on the probability of retaining deputies as candidates.

Among the personal characteristics of deputies that could influence their being retained as future candidates we include the following variables. Ranknaz measures the national ranking of the individual legislator within her party based on the number of preference votes received. We expect the sign of the estimated coefficient of this variable to be negative (note that ranknaz 
equals one for the candidate receiving the highest number of preference votes among all candidates of the same party in any given election). Deputies with larger personal electoral followings should have been more likely to be reselected.

We consider two dummy variables to indicate whether the deputy is a minister or an undersecretary ( $d \_$min and $d \_$undermin). Inasmuch as occupying a ministerial position allows a representative to reap an unusual incumbency benefit, we would expect the estimated coefficients for these variables to be positive. We also consider the educational attainment of the deputy (educ), the deputy's gender (sex), and whether he served as a member of his party's executive or central committee (partyexp). We expect the signs on each of these to be positive.

Last, we include dummy variables that indicate the number of prior terms served. These variables are called $L 2 u t, L 3 u t$, etc., to indicate that a given deputy had already served two, three, etc. terms, including the term she is currently serving. We do not include the variable $L 1 u t$ because it would be equal to 1 for all deputies, since we only consider incumbents. The presence of these dummy variables allows to test whether parties did have an incentive to "retire" deputies after some terms in office.

We estimate separate models for the DC and for the PSI over elections for the Second through the Tenth Legislatures (we omit the First because there were no incumbents running.) Our results are reported in Table $2 .^{12}$

\section{Table 2 about here}

The results are qualitatively similar for the two parties. We do not observe any significant influence of past party performance in the district (the DDC_dif and DPSI_dif variables, respectively for the $D C$ and for the $P S I)$. For the DC, we detect a statistically significant and 
important effect of the lagged ranknaz variable, indicating that incumbents who ranked highly in the national party in the number of preference votes received in the prior election had a greater chance of being reselected. A similar effect is also found for the PSI but is not statistically significant. For both parties, being a minister also helps in being allowed to run again for election, as does, to a smaller extent, being an undersecretary for the DC (but not for the PSI). Such effects are pronounced. Serving as a government minister increases the probability that a DC incumbent is relisted by 9 percent and being an undersecretary by 5 percent. For PSI incumbents, being a minister increases the probability of being relisted by 15 percent. ${ }^{13}$

As we show in the next section, the probability of occupying a ministerial position, in turn, was for both parties significantly affected by the national ranking in preference votes, so that the two variables have to be seen as being strictly connected. That is, promotion to government office hinged on having amassed preference votes.

The results also show that older deputies in both parties experienced electoral advantages. The presence of age squared, appearing with a negative estimated coefficient, captures the fact that after a certain age, age no longer confers political advantage. For both parties, the age and age squared are jointly statistically significant. The estimated coefficients imply that age becomes a disadvantage at 59 years in the DC, while for the PSI a positive effect is estimated to be present only until age 40 .

Our results also indicate that the probability of being retained as a candidate was negatively influenced by the number of terms already served. This is documented by the many negative signs on the estimated coefficients of the dummy variables indicating the number of terms served ( $L 2 u t, L 3 u t$, etc.). For the DC, but not for the PSI, these estimated coefficients often 
reach conventional levels of statistical significance. The DC, in deciding whether to retain an incumbent as a candidate, penalized incumbents who had served three or more terms.

We also consider the educational attainment of the deputy $(e d u c)$, the deputy's gender (sex), and whether he served as a member of his party's executive or central committee (partyexp).${ }^{14}$ These variables do not have significant effects, with the exception of educational attainment, which positively influences the probability that PSI incumbents will be relisted as candidates.

Taken together, these results suggest that legislators in the two major parties of government enjoyed no particular incumbency advantage. Indeed, those affiliated with the DC were rapidly "churned" off party lists after having served only two or three terms. In that party, however, a very small number of elite deputies who had received large numbers of preference votes relative to other DC candidates across Italy also existed. This small elite often served in ministerial positions and, also thanks to that, enjoyed a much longer tenure than the average deputy, although even these men may have always experienced some threat of being excluded from the list. The precariousness of access to legislative office suggests that deputies would have had powerful incentives to work to distinguish themselves from competitors to attract preference votes. This in turn gave elite deputies incentives to pork barrel.

\section{Empirical Analysis Incorporating the Allocation of Resources into the Model}


Above, we used two different estimation techniques (regression discontinuity analysis and probit) to construct baseline models, the results of which both document that the average Italian legislator, like his Indian counterpart (Chakrabarti, Gangopadhyay, and Krishnan n.d.; Linden 2004; Uppal 2005) and in contrast to U.S. legislators, enjoys no apparent incumbency advantage in subsequent electoral contests. A large part of the explanation for this is the decision by the incumbent's party to exclude him from the party list after only a few terms in office. We now expand our analysis to study whether promotion to a ministerial position or allocating more pork and patronage to electoral districts improves the electoral fortunes of incumbents. We assess whether these activities increase the number of preference votes received, thereby improving the chances that the incumbent will be inoculated against being removed from the party list. We also study whether the two main parties of government had independent incentives to distribute pork barrel and patronage; that is, whether the allocation of more resources increased list votes for the DC and PSI.

\section{The Data and Structure of Analysis of Pork and Patronage}

Thus far, our results endorse existing but empirically less complete studies (Cotta 1979) that argue that there is a distinction in postwar Italy between a small party elite and large mass of deputies who were deselected by their party after only a few terms. This aggregate outcome offers the average incumbent no advantage in contesting elections. We expect rational political actors to anticipate this and to behave strategically by attempting to construct political advantage based on the allocation of benefits to their constituents.

In this section, we study the distribution of two kinds of government benefits: infrastructure investments, which are geographically localized but not finely targetable to individual voters, and disability pensions, which are targetable to individual voters. Public 
investments comprised a substantial portion of total public expenditures during the years we study, from as much as 21 percent of total public outlays in 1961 and falling below 10 percent only in the 1992-94 period. Over the forty-odd years for which we have data, public works on average absorbed 15 percent of total public expenditures, corresponding to 2.5 percent of national net product. Hence, the discretionary expenditures that we analyze were substantively large. Likewise, the number of disability pensions was also large. On average, 7 percent of the Italian population received disability pensions over the period we study, with a peak above 13 percent in the Sixth and Seventh Legislatures.

For the models that we estimate, we do not use all the observations potentially at our disposal, both because the model is dynamic and also because the expenditure data is available only from the Second Legislature onwards. Our data on public investments refers to annual flows of capital expenditures (in constant millions of 1990 lire) for public construction in Italy's electoral districts, summed over the life of each legislature. Our data on disability pensions is the average annual stock of pensions distributed in the district during the legislative period. We also include measures of the average individual characteristics of deputies in the district (such as average educational attainments). We estimate models separately for the DC and the PSI.

We examine the impact of the distribution of both kinds of goods on party (list) votes, on individual (preference) votes, and on the ability of politicians to mobilize voters, that is, to encourage them to use their available preference votes. The dependent variable is one of three measures of votes to a party in a given district in a given legislatures:

PVOTES: preference votes received by a candidate;

VOTES: votes to the party within the district, percentage; 
PVOTERATIO: the sum of preference votes cast by DC or PSI voters in a district divided by the number of list votes. ${ }^{15}$

This final measure captures whether the allocation of benefits affects list or preference votes in more or less equal measure. In all of our estimations, we model how the distribution of benefits during the life of the legislature affects outcomes in the next parliamentary election. This solves possible problems of endogeneity and is the natural structure given the underlying story: parties and politicians distribute benefits hoping to secure an electoral advantage in the next period. Whether they are successful is revealed when elections are held.

\section{Determinants of Preference Votes to Legislators}

To study whether individual deputies are able to appropriate credit for distributive resources, successfully transforming them in preference votes, we model the impact of the distribution of pork and patronage and of other variables on the (log of the) number of preference votes received by deputies. We assume that the number of preference votes received by a deputy follows an autoregressive process: deputies who receive many preference votes in one election also tend to receive many in the following. If deputies are able to appropriate political credit for distributive resources to the district, we expect a positive and significant sign on the estimated coefficient for both of our expenditure variables (since high ranking deputies have a low rank order). Moreover, being a minister or an undersecretary may help secure preference votes regardless of any advantage that such an position entail for routing public expenditures to the district. Table 3 reports results of our analysis.

\section{Table 3 about here}


For both parties, we detect a strong autoregressive component in the number of preference votes received by incumbents. For the DC, we also see a positive and significant effect in holding a government position. In the case of PSI, the estimated coefficients, while properly signed, are not precisely estimated. For both parties, as intuition would suggest, we detect a stronger benefit to being a minister than to being a less influential undersecretary. The electoral benefits to being in government are strong. Being a minister (undersecretary) causes a 17 percent (10 percent) increase in preference votes to a DC incumbent. Being a minister also increased the preference votes received by a PSI incumbent by 23 percent.

Where districts receive more capital investments, DC deputies (but not those in the PSI) see improvements in the number of preference votes they receive. Where districts receive more disability pensions, PSI deputies (but not those in the DC) see increases in the number of preference votes that they receive. However, the size of the estimated effects are modest. Our estimates imply that a 10 percent increase in public investment accruing to a district increases preference votes to DC incumbents by only 0.2 percent, and an analogous increase in disability pensions causes an increase of preference votes to PSI incumbents in the order of 1 percent.

These findings speak to the results reported earlier that document a sharp distinction between a large number of incumbents who enjoy no incumbency advantages and a small number of powerful elite legislators. Elite legislators, who remain in office for many terms, do so in part because they receive ministerial positions and also, to a smaller but detectable extent, because of their success in politically exploiting the allocation of pork and patronage to their districts. We note as well that this finding contradicts literature in comparative politics that assumes that credit claiming in multimember settings is all but impossible. Our results document 
that the most powerful deputies in Italy's two major parties of government were effective in their abilities to appropriate credit for the distribution of benefits to their districts.

\section{Determinants of List Votes}

We now focus on party votes (as opposed to personal preference votes) in electoral districts. Here our data now form a panel of $N=30$ districts times $T=11$ legislatures, for a total of 330 observations. We first ask whether party list votes increase with more pork and patronage. We assume an autoregressive structure of party votes and we also include the size of the electorate as a regressor. Lagged GDP at constant prices is included to capture any macroeconomic effects on voting behavior. Table 4 reports the results of these estimates when the dependent variable is the percentage of votes to the party for the DC and the PSI separately. The equation is estimated using an Arellano-Bond 1-step estimator (Roodman 2006).

\section{Table 4 about here}

The results show that lagged GDP has a negative and significant effect on DC votes and a positive but insignificant effect on votes to PSI. In addition, the lagged number of incumbents in the district who were either ministers $\left(L d \_\right.$min_DC or $L d \_$min_PSI) or undersecretaries (Ld_undermin_DC or $\left.L d \_u n d e r m i n \_P S I\right)$ does not positively affect votes to their parties and in one case (that of PSI ministers) has a significant negative effect on that party's list votes. While being a minister turned out to be very useful for personal vote getting by an incumbent, it fails to confer a benefit to the party in the minister's home district.

Lagged disability pensions significantly and positively affect the share of votes to the DC and to the PSI, although the latter result just fails to achieve conventional levels of statistical significance. Lagged capital expenditures positively and significantly affect votes to the PSI. 
These results suggest that these two parties target these resources strategically to districts in order to enhance their list votes. Hence, the interests of the parties and their most powerful legislators coincide in that both benefit electorally from pork and patronage. The PSI appears to have been especially strategic in securing new infrastructure and appropriating political credit for it, while for the DC we detect an effect only of disability pensions. The effects that we estimate, however, are substantively modest. An increase of 10 percent in public investments increases votes to the DC by 0.28 percent and an equal increase in disability pensions increases votes to the PSI by about 0.3 percent.

\section{Determinants of the Ratio of Preference to List Votes}

We now study whether individual legislators or their parties benefit in equal measure or disproportionately with the distribution of investments and disability pensions to districts. We do this with a model with pvoteratio as the dependent variable. This captures the ratio of preference votes to total list votes; the maximum value is three (or in very large districts, four). Our results are reported in Table 5, and are again obtained using the Arellano-Bond 1-step procedure.

\section{Table 5 about here}

We find some evidence that the number of DC ministers and PSI undersecretaries in the district positively affects the ratio of preference to list votes, and results are close to the conventional cutoff for statistical significance of 10 percent. In the most optimistic of cases, an extra DC minister in the district implies an increase of 5 percent in the ratio of preference votes to total votes cast for the DC. Results reported in the table show also no statistical impact of changes in expenditures on the ratio of preference to list votes for the DC. That is, when the average number of disability pensions increases, it positively affects both list votes and 
preference votes for the DC and it does so in roughly equal measure. We interpret this as evidence that pork and patronage were mainly used by Christian Democratic deputies to gain votes from challengers within their own party.

For the PSI, on the other hand, the effect is significant and positive for disability pensions. This suggests that when more pork and patronage were distributed, the PSI gained list votes but its legislators gained even more individual preference votes. We interpret this as documenting the specific importance to Socialist deputies of mobilizing their clientele and encouraging them to use their preference votes in increasingly conflictual intra-party environment. Elite Socialist deputies had greater success than their party in transforming any allocations of pork and patronage to their districts into votes. This corroborates the general impression that the PSI was controlled by a party elite, especially under the leadership of Bettino Craxi, whose political reputation was independent of and distinct from their partisan affiliation.

\section{Political Discounting of Preference Votes}

We now address whether parties discounted large numbers of preference votes received in areas where voters cast relatively many preference votes, as occurred in Italy's southern electoral districts. Figure 2 shows boxplots of the ratio of preference votes to party votes separately for the DC and the PSI for the 11 elections we study. For both parties, districts in southern Italy (roughly, the higher numbered districts) display higher values for the ratio, and this is true not only for the DC, for which this phenomenon is well known, but also for the PSI. In addition, the data depicted in the boxplots shows that DC electors had a higher propensity to cast preference votes than did Socialist voters.

\section{Figure 2 about here}


Since electoral districts in southern Italy saw much higher numbers of preference votes cast, it is likely that at national party headquarters and in government this was politically discounted, so that in order to obtain a given level of political clout a deputy needed a higher number of preference votes if he represented a southern district. We investigate this by estimating a probit model where the dependent variable is a dummy variable indicating whether a deputy was awarded a ministerial position or not and where the ratio of preference votes to total party votes in his district appears as an independent variable along with that deputy's individual ranking within his party. We also include the squared term of the ranking variable for the same reason as indicated earlier; namely, it offers additional flexibility in the parameterization. If any downward adjustments were made in districts where voters used large numbers of preference votes, we expect the estimated coefficient on the ratio variable to be negative and significant. Table 6 reports the results of such an exercise.

\section{Table 6 about here}

For both the DC and the PSI, the negative and highly significant coefficient on ranknaz underscores the positive effects that preference votes had on the prospect of becoming a minister or an undersecretary (recall that ranknaz is equal to one for the deputy who received the highest number of preference votes across all of Italy in his party). For the DC, the variable pvoteratio has a negative and significant estimated coefficient, indicating a downward adjustment in districts where relatively many preference votes were cast. Such an adjustment is not present for the PSI. We also find that Christian Democratic deputies had higher probabilities of entering government if they were better educated or if they had held party offices. For the PSI, the estimated coefficient on the sex variable is positive and significant, indicating that males had a higher probability of landing ministerial positions than females even with the same ranking 
nationally in preference votes. The probability of being selected for a ministerial position also increases with age, with an effect that is attenuated and then reverses for older deputies.

We also consider the possible role of past tenure with the inclusion of the dummy variables $L 2 u t, L 3 u t$, etc. The estimated signs are always positive and often significant, particularly for the DC. This shows that having served for many legislatures significantly increases the odds of being selected for a ministerial position.

The results reported in Table 6 document that in the DC in order to obtain a ministerial position the value of preference votes was adjusted downward in those (southern) districts where voters more often cast preference votes. However, such an adjustment probably did not entirely cancel out the effects of preference votes. To determine if this is the case, we revert again to a panel structure for the data, with $N=30$ districts times $T=11$ legislatures, for a total of 330 observations. We undertake a poisson regression where the number of DC government positions accruing to deputies elected from each district is explained by the number of list votes to the DC and by the variable pvoteratio. Results are reported in Table $7 .{ }^{16}$

\section{Table 7 about here}

Votes to the party in the district positively influence the number of ministerial positions held by deputies elected from that district. We see that the estimated coefficient on the pvoteratio variable is positive and significant, indicating that the downward adjustment that we identified for the DC did not entirely cancel out the positive effects of having mobilized many preference votes given the number of party voters. This suggests that deputies in each district experienced collective incentives to mobilize their electorate to use their preference votes because doing so increased the number of government positions awarded to deputies elected from the district. 
Even while competing with each other for preference votes, deputies in each party shared interests in mobilizing voters to use their available preference votes.

\section{Conclusions}

Our analysis found no overall electoral advantage accruing to incumbents in Italy's postwar Chamber of Deputies. Simply having served as a national legislator did not help Christian Democratic or Socialist deputies achieve reelection. Instead, it was very difficult for all but a handful of elite deputies to be reselected by the party after only a few terms. Most deputies were churned out of the Chamber, presumably moving into another party position or any one of myriad public offices; Italy had more than 3 million elected officials between 1986 and 2002, as well as uncounted fulltime positions working for the numerous political parties (Bearman and Parigi 2008).

Related to the electoral insecurity of political incumbents, postwar Italian politics was well known for having been especially rife with patronage and pork. The distribution of geographically and individually targetable goods was, we have documented, politically advantageous for the small number powerful individual deputies in the DC and PSI as well for the shares of votes obtained by these two parties. Credit-claiming, in other words, was possible for deputies once they had assembled large clienteles and served in office for enough terms to become individually identifiable by the electorate. As more government goods are directed to electoral districts, voters respond by using more of the individual votes available to them as well as supporting these two major parties.

Our results resonate with the current debate between Stokes (2005) and Nichter (2008) about whether political machines distribute goods in order to gain votes or in order to mobilize

turnout. We find that both views are correct. More resources to a district mobilize voters to use 
more preference votes (which we may think of as a measure of turnout) and also gains powerful deputies more preference votes. The latter in turn increases their chances of being offered a ministerial position, thereby protecting them from being removed from the party list in the next electoral encounter, and, finally, swings more votes to the party.

Finally, this study is one of the first to unpack the concept of incumbency advantage in a multiparty multimember political setting governed by open list proportional representation. Most of what understand about how politicians manipulate the institutional and political environment to improve their chances of reelection comes from studies of the United States. There, it seems that both major parties and all legislators benefitted from the growing incumbency advantage that characterized the twentieth century. The postwar Italian context, by contrast, is one in which only a small leadership group enjoyed an incumbency advantage. This suggests party organizations in which top leaders probably maintained strong control of candidate selection and political recruitment. Whether this finding extends to other open list systems of proportional representation is yet to be known. 


\section{References}

Ames, Barry. 1995. "Electoral Strategy under Open-List Proportional Representation." American Journal of Political Science 39 (May): 406-33.

Bearman, Peter S. and Palo Parigi. 2008. "Spaghetti Politics: Local Electoral Systems and Alliance Structure in Italy, 1984-2001.” Social Forces 87 (Dec.): 623-49.

Beck, Thorsten, Clarke, George, Groff, Alberto, Keefer, Philip and Walsh, Patrick. 2001. "New Tools in Comparative Political Economy: The Database of Political Institutions." World Bank Economic Review 15 (Jan.): 165-76.

Cain, Bruce E., Ferejohn, John A., and Fiorina, Morris P. 1984. "The Constituency

Service Basis of the Personal Vote for U.S. Representatives and British Members of Parliament." American Political Science Review 78 (March): 110-25.

Carey, John M. and Shugart, Matthew Sobert. 1995. "Incentives to Cultivate a Personal Vote: a Rank Ordering of Electoral Formulas.” Electoral Studies 14 (Dec.): 417-39.

Chakrabarti, Rajesh, Gangopadhyay, Shubhashis, and Krishnan, Shagun. N.d. "Incumbency Effects in Indian Elections - A Preliminary Exploration." Unpublished paper.

Cotta, Maurizio. 1979. Classe politica e parlamento in Italia. Bologna: Il Mulino.

Cox, Gary W. and Morgenstern, Scott. 1995. "The Incumbency Advantage in Multimember Districts: Evidence from the U.S. States.” Legislative Studies Quarterly 20 (Aug.): 329-49.

Crisp, Brian F. and Desposato, Scott W. 2004. "Constituency Building in Multimember Districts: Collusion or Conflict?” Journal of Politics 66 (Feb.): 136-56.

Diermeier, Daniel, Keane, Michael, and Merlo, Antonio. 2005. "A Political Economy Model of Congressional Careers." American Economic Review 95: 347-73.

Ferejohn, John A. 1974. Pork Barrel Politics: Rivers and Harbors Legislation, 19471968. Stanford: Stanford University Press.

Golden, Miriam and Picci, Lucio. 2005. "Proposal for a New Measure of Corruption, Illustrated with Italian Data." Economics \& Politics 17 (March): 37-75.

Golden, Miriam and Picci, Lucio. 2008. "Pork Barrel Politics in Postwar Italy, 1953-

1994." American Journal of Political Science 52 (April): 268-89.

Imbens, Guido W. and Lemieux, Thomas. 2008. "Regression Discontinuity Designs: A Guide to Practice." Journal of Econometrics, 142 (Feb): 615-35.

Katz, Jonathan N. and King, Gary. 1999. "A Statistical Model for Multiparty Electoral

Data." American Political Science Review 93 (March): 15-32.

Katz, Richard S. and Bardi, Luciano. 1980. "Preference Voting and Turnover in Italian

Parliamentary Elections." American Journal of Political Science 24 (Feb.): 97-114.

Katz, Richard S. 1986. "Intraparty Preference Voting." In Electoral Laws and Their

Political Consequences, ed. Bernard Grofman and Arend Lijphart. New York: Agathon Press.

Lancaster, Thomas D. 1986. "Electoral Structures and Pork Barrel Politics." International Political Science Review 7 (Jan.): 67-81.

Lee, David S. 2008. "Randomized Experiments from Non-Random Selection in U.S.

House Elections." Journal of Econometrics 142: 675-97.

Lee, David S. and Lemieux, Thomas. 2010. "Regression Discontinuity Designs in Economics." Journal of Economic Literature 48 (June): 281-355.

Linden, Leigh L. 2004. "Are Incumbents Really Advantaged? The Preference for NonIncumbents in Indian National Elections." Unpublished paper. 
Merlo, Antonio, Galasso, Vincenzo, Landi, Massimiliano, and Mattozzi, Andrea. 2009. "The Labor Market of Italian Politicians." Penn Institute for Economic Research Working Paper $09-024$.

Nichter, Simeon. 2008. "Vote Buying or Turnout Buying? Machine Politics and the Secret Ballot." American Political Science Review 102: 19-31.

Persson, Torsten and Tabellini, Guido. 2003. The Economic Effects of Constitutions. Cambridge: MIT Press.

Roodman, David. 2006. "How to Do xtabond2: An Introduction to 'Difference' and 'System' GMM in Stata." Center for Global Development, Working Paper 103. December. Stokes, Susan C. 2005. "Perverse Accountability: A Formal Model of Machine Politics with Evidence from Argentina." American Political Science Review 99 (Aug.): 315-25.

Uppal, Yogesh. 2005. "The (Dis)advantaged Incumbents: Estimating Incumbency Effects in Indian State Legislatures." Unpublished paper.

Van de Ven, Wynard P. M. M. and Van Pragg, Bernard M.S. 1981. "The Demand for Deductibles in Private Health Insurance: A Probit Model with Sample Selection." Journal of Econometrics 17: 229-52. 


\section{Tables and Figures}

Table 1. Tenure in parliament for DC and PSI deputies (1994-1992)

\begin{tabular}{lccccccc} 
& \multicolumn{9}{c}{ DC } & & \multicolumn{3}{c}{ PSI } \\
\cline { 2 - 4 } \cline { 7 - 8 } Term & Frequency & Percentage & $\begin{array}{c}\text { Cumulative } \\
\text { percentage }\end{array}$ & & Frequency & Percentage & $\begin{array}{c}\text { Cumulative } \\
\text { percentage }\end{array}$ \\
\hline 1 & 313 & 31.39 & 31.39 & & 119 & 36.39 & 36.39 \\
2 & 220 & 22.07 & 53.46 & & 88 & 26.91 & 63.30 \\
3 & 151 & 15.15 & 68.61 & & 56 & 17.13 & 80.43 \\
4 & 147 & 14.74 & 83.35 & & 32 & 9.79 & 90.21 \\
5 & 74 & 7.42 & 90.77 & & 17 & 5.20 & 95.41 \\
6 & 52 & 5.22 & 95.99 & & 10 & 3.06 & 98.47 \\
7 & 19 & 1.91 & 97.89 & & 3 & 0.92 & 99.39 \\
8 & 11 & 1.10 & 99.00 & & 1 & 0.31 & 99.69 \\
9 & 5 & 0.50 & 99.50 & & 0 & 0.00 & 99.69 \\
10 & 5 & 0.50 & 100 & & 1 & 0.31 & 100 \\
\hline Total & 997 & 100 & & 327 & 100 & \\
\hline
\end{tabular}

Note: Deputies who changed party in the course of their careers were excluded. 
Table 2. Determinants of the inclusion of incumbents on the ballot

\begin{tabular}{|c|c|c|}
\hline & DC & PSI \\
\hline DDC_dif & $\begin{array}{l}-0.006 \\
(0.017)\end{array}$ & \\
\hline DPSI_dif & & $\begin{array}{c}-0.014 \\
(0.059)\end{array}$ \\
\hline ranknaz & $\begin{array}{c}-0.001 * * * \\
(0.00)\end{array}$ & $\begin{array}{c}-0.002 \\
(0.002)\end{array}$ \\
\hline d_min & $\begin{array}{c}0.407 * * * \\
(0.141)\end{array}$ & $\begin{array}{c}0.969 * * \\
(0.431)\end{array}$ \\
\hline d_undermin & $\begin{array}{c}0.198 * * \\
(0.099)\end{array}$ & $\begin{array}{c}0.122 \\
(0.253)\end{array}$ \\
\hline agedep & $\begin{array}{c}0.066 \\
(0.049)\end{array}$ & $\begin{array}{c}0.024 \\
(0.054)\end{array}$ \\
\hline agedepsq & $\begin{array}{c}-0.001 * * \\
(0.00)\end{array}$ & $\begin{array}{l}-0.001 \\
(0.001)\end{array}$ \\
\hline $\operatorname{sex}$ & $\begin{array}{l}-0.152 \\
(0.185)\end{array}$ & $\begin{array}{l}-0.377 \\
(0.513)\end{array}$ \\
\hline educ & $\begin{array}{c}0.012 \\
(0.029)\end{array}$ & $\begin{array}{l}0.110^{*} \\
(0.064)\end{array}$ \\
\hline partyexp & $\begin{array}{l}-0.021 \\
(0.016)\end{array}$ & \\
\hline L2ut & $\begin{array}{l}-0.227 \\
(0.182)\end{array}$ & $\begin{array}{c}-0.071 \\
(0.230)\end{array}$ \\
\hline L3ut & $\begin{array}{c}-0.51 * * * \\
(0.193)\end{array}$ & $\begin{array}{c}-0.403 \\
(0.268)\end{array}$ \\
\hline L4ut & $\begin{array}{c}-0.66 * * * \\
(0.199)\end{array}$ & $\begin{array}{c}0.095 \\
(0.359)\end{array}$ \\
\hline L5ut & $\begin{array}{c}-0.619 * * * \\
(0.221)\end{array}$ & $\begin{array}{c}-0.965^{* *} \\
(0.404)\end{array}$ \\
\hline L6ut & $\begin{array}{c}-0.797 * * * \\
(0.242)\end{array}$ & $\begin{array}{c}0.006 \\
(0.881)\end{array}$ \\
\hline L7ut & $\begin{array}{c}-0.43 \\
(0.338)\end{array}$ & $\begin{array}{l}-0.835 \\
(0.806)\end{array}$ \\
\hline L8ut & $\begin{array}{c}-0.617^{*} \\
(0.346)\end{array}$ & \\
\hline L9ut & $\begin{array}{c}0.062 \\
(0.649)\end{array}$ & \\
\hline L10ut & $\begin{array}{c}-0.08 \\
(0.829)\end{array}$ & \\
\hline $\begin{array}{l}\text { Joint signif., } \\
\text { age }\end{array}$ & $0.0042 * * *$ & \\
\hline
\end{tabular}

Note: Relist $=1$ if deputy ran, 0 otherwise. Lranknaz = lagged national ranking of deputy within party; L2ut: 1 if the deputy sat in the two previous legislature; L3ut: etc. Only incumbent deputies are considered (for all of them, L1ut would have been equal to 1 and hence L1ut is not used as a regressor). Robust standard errors in parentheses. ${ }^{* * *}$ denotes $\mathrm{p}<0.01{ }^{* *} \mathrm{p}<0.05{ }^{*} \mathrm{p}<0.10$ 
Table 3. Appropriability of distributive resources by deputies

\begin{tabular}{lcc} 
& DC & PSI \\
\hline Llpvotes & $0.863^{* * *}$ & $0.867 * * *$ \\
& $(0.021)$ & $(0.030)$ \\
Ld_min & $0.161^{* * *}$ & 0.078 \\
& $(0.034)$ & $(0.068)$ \\
Ld_undermin & $0.100^{* * *}$ & 0.013 \\
& $(0.022)$ & $(0.057)$ \\
LDlinvtot & $0.055^{* *}$ & 0.002 \\
& $(0.026)$ & $(0.060)$ \\
LDlinps_el & -0.011 & $0.284 * *$ \\
& $(0.063)$ & $(0.121)$ \\
& & \\
$\mathrm{N}$ & 1480 & 379 \\
MSS & 303.901 & 155.018 \\
RSS & 117.414 & 44.466 \\
RMSE & 0.283 & 0.348 \\
$\mathrm{R}^{2}$ & 0.721 & 0.777 \\
adjusted $\mathrm{R}^{2}$ & 0.719 & 0.77 \\
\hline Note: Leg dummies and constant not reported. & Robust standard errors in \\
parentheses. $* * *$ denotes $\mathrm{p}<0.01 * * \mathrm{p}<0.05 * \mathrm{p}<0.10$ &
\end{tabular}


Table 4. Determinants of party list votes

\begin{tabular}{|c|c|c|}
\hline & DC & PSI \\
\hline LlvotesDC & $\begin{array}{c}0.126 \\
(0.106)\end{array}$ & \\
\hline Ld_min_DC & $\begin{array}{l}-0.008 \\
(0.015)\end{array}$ & \\
\hline Ld_undermi $\sim \mathrm{C}$ & $\begin{array}{c}-0.016 \\
(0.010)\end{array}$ & \\
\hline LlvotesPSI & & $\begin{array}{c}0.35 * * * \\
(0.118)\end{array}$ \\
\hline Ld_min_PSI & & $\begin{array}{c}-0.144 * * \\
(0.069)\end{array}$ \\
\hline Ld_undermi $\sim \mathrm{I}$ & & $\begin{array}{c}0.003 \\
(0.041)\end{array}$ \\
\hline lelettori & $\begin{array}{c}1.217 * * * \\
(0.208)\end{array}$ & $\begin{array}{c}1.294 * * \\
(0.586)\end{array}$ \\
\hline Llgdp90 & $\begin{array}{l}-0.14^{*} \\
(0.080)\end{array}$ & $\begin{array}{c}0.487 \\
(0.338)\end{array}$ \\
\hline Llinvtot & $\begin{array}{l}-0.035 \\
(0.027)\end{array}$ & $\begin{array}{c}0.108 * * \\
(0.040)\end{array}$ \\
\hline Llinps_el & $\begin{array}{c}0.076^{* *} \\
(0.031)\end{array}$ & $\begin{array}{c}0.212 \\
(0.149)\end{array}$ \\
\hline $\mathrm{N}$ & 210 & 210 \\
\hline
\end{tabular}

Note: Leg dummies and constant included in the regression and omitted from this table.

DC: Arellano-Bond test for AR(1) in first differences: $\mathrm{z}=-2.77 \operatorname{Pr}>\mathrm{z}=0.006$

Arellano-Bond test for AR(2) in first differences: $z=-0.98 \operatorname{Pr}>z=0.328$

Arellano-Bond test for AR(3) in first differences: $z=1.14 \operatorname{Pr}>z=0.255$

Arellano-Bond test for AR(4) in first differences: $z=0.43 \operatorname{Pr}>z=0.665$

Sargan test of overid. restrictions: chi2(32) $=86.90$ Prob $>$ chi2 $=0.000$

(Not robust, but not weakened by many instruments.)

Hansen test of overid. restrictions: $\operatorname{ch} 2(32)=22.33$ Prob $>$ chi2 $=0.898$

(Robust, but can be weakened by many instruments.)

PSI: Arellano-Bond test for AR(1) in first differences: $z=-3.72 \operatorname{Pr}>z=0.000$

Arellano-Bond test for AR(2) in first differences: $z=-1.20 \operatorname{Pr}>z=0.230$

Arellano-Bond test for AR(3) in first differences: $z=0.68 \operatorname{Pr}>z=0.496$

Arellano-Bond test for AR(4) in first differences: $z=-0.22 \operatorname{Pr}>z=0.829$

Sargan test of overid. restrictions: $\operatorname{chi} 2(25)=70.78$ Prob $>$ chi $2=0.000$

(Not robust, but not weakened by many instruments.)

Hansen test of overid. restrictions: $\operatorname{chi} 2(25)=20.43$ Prob $>\operatorname{chi} 2=0.724$

(Robust, but can be weakened by many instruments.)

$* * *$ denotes $\mathrm{p}<0.01 * * \mathrm{p}<0.05 * \mathrm{p}<0.10$ 
Table 5. Determinants of the ratio of preference to list votes

\begin{tabular}{lcc} 
& DC & PSI \\
\hline Lpvoterati $\sim C$ & -0.033 & \\
& $(0.101)$ & \\
Ld_min_DC & 0.053 & \\
& $(0.034)$ & \\
Ld_undermi $\sim C$ & -0.004 & \\
& $(0.018)$ & \\
Lpvoterati $\sim$ I & & 0.097 \\
& & $(0.120)$ \\
Ld_min_PSI & & 0.003 \\
& & $(0.083)$ \\
Ld_undermi I & & 0.08 \\
& & $(0.049)$ \\
Llinvtot & -0.045 \\
& $(0.038)$ & $(0.039)$ \\
Llinps_el & -0.094 & $0.259^{* *}$ \\
& $(0.075)$ & $(0.105)$ \\
& 0.217 & 0.019 \\
$\mathrm{~N}$ & & \\
\hline
\end{tabular}

Note: Leg dummies and constant not reported. Robust standard errors in parentheses. ${ }^{* * *}$ denotes $\mathrm{p}<0.01 * * \mathrm{p}<0.05 * \mathrm{p}<0.10$ 
Table 6. Downward adjustment in the value of a preference vote

\begin{tabular}{|c|c|c|}
\hline & DC & PSI \\
\hline pvoteratio $\sim \mathrm{C}$ & $\begin{array}{c}-0.465 * * * \\
(0.079)\end{array}$ & \\
\hline pvoteratio $\sim \mathrm{I}$ & & $\begin{array}{c}0.002 \\
(0.177)\end{array}$ \\
\hline ranknaz & $\begin{array}{c}-0.005^{* * *} * \\
(0.000)\end{array}$ & $\begin{array}{c}-0.007 * * \\
(0.003)\end{array}$ \\
\hline agedep & $\begin{array}{c}0.152 * * * \\
(0.038)\end{array}$ & $\begin{array}{c}0.277 * * * \\
(0.104)\end{array}$ \\
\hline agedepsq & $\begin{array}{c}-0.002 * * * \\
(0.000)\end{array}$ & $\begin{array}{c}-0.003 * * * \\
(0.001)\end{array}$ \\
\hline educvar & $\begin{array}{c}0.333 * * * \\
(0.100)\end{array}$ & $\begin{array}{c}0.147 \\
(0.209)\end{array}$ \\
\hline sex & $\begin{array}{c}-0.199 \\
(0.181)\end{array}$ & $\begin{array}{l}1.11 * * \\
(0.447)\end{array}$ \\
\hline partyexp & $\begin{array}{c}0.066^{* * *} * \\
(0.013)\end{array}$ & $\begin{array}{l}-0.038 \\
(0.031)\end{array}$ \\
\hline L2ut & $\begin{array}{c}1.195 * * * \\
(0.128)\end{array}$ & $\begin{array}{c}0.747 * * * \\
(0.19)\end{array}$ \\
\hline L3ut & $\begin{array}{c}1.776^{* * * *} \\
(0.136)\end{array}$ & $\begin{array}{c}0.888 * * * \\
(0.229)\end{array}$ \\
\hline L4ut & $\begin{array}{c}1.969 * * * \\
(0.149)\end{array}$ & $\begin{array}{c}0.764 * * * \\
(0.275)\end{array}$ \\
\hline L5ut & $\begin{array}{c}1.865^{* * * *} \\
(0.172)\end{array}$ & $\begin{array}{c}0.282 \\
(0.426)\end{array}$ \\
\hline L6ut & $\begin{array}{c}1.614 * * * \\
(0.206)\end{array}$ & $\begin{array}{c}0.263 \\
(0.614)\end{array}$ \\
\hline L7ut & $\begin{array}{c}0.943 * * * \\
(0.308)\end{array}$ & \\
\hline L8ut & $\begin{array}{c}1.119 * * * \\
(0.366)\end{array}$ & \\
\hline L9ut & $\begin{array}{c}2.259 * * * \\
(0.535)\end{array}$ & \\
\hline L10ut & $\begin{array}{c}2.57 * * * \\
(0.727)\end{array}$ & \\
\hline $\mathrm{d} 2$ & $\begin{array}{c}-0.526 * * * \\
(0.176)\end{array}$ & \\
\hline $\mathrm{d} 3$ & $\begin{array}{c}-0.811 * * * \\
(0.182)\end{array}$ & \\
\hline d4 & $\begin{array}{c}-1.241 * * * \\
(0.189)\end{array}$ & $\begin{array}{c}-0.452^{*} \\
(0.273)\end{array}$ \\
\hline
\end{tabular}




\begin{tabular}{lcc} 
d5 & $-0.886^{* * *}$ & -0.096 \\
& $(0.183)$ & $(0.303)$ \\
d6 & $-1.063 * * *$ & -0.091 \\
& $(0.185)$ & $(0.262)$ \\
d7 & $-1.144 * * *$ & \\
& $(0.185)$ & \\
d8 & $-1.018 * * *$ & $0.485^{*}$ \\
& $(0.182)$ & $(0.263)$ \\
d9 & $-1.392 * * *$ & -0.025 \\
& $(0.189)$ & $(0.241)$ \\
d10 & $-0.969 * * *$ & \\
& $(0.181)$ & \\
& & \\
N & 2391 & 374 \\
R2 p p & 0.243 & 0.146 \\
\hline
\end{tabular}

Note: Leg dummies and constant not reported. Robust standard errors in parentheses. $* * *$ denotes $\mathrm{p}<0.01 * * \mathrm{p}<0.05 * \mathrm{p}<0.10$ 
Table 7: Determinants of the district's total number of ministerial positions

\begin{tabular}{lcc} 
& DC & PSI \\
\hline lvotesDC & $0.883^{* * *}$ & \\
& $(0.061)$ & \\
pvoteratio $\sim \mathrm{C}$ & $0.326^{* * *}$ & \\
& $(0.053)$ & \\
lvotesPSI & & $0.671^{* * *}$ \\
& & $(0.185)$ \\
pvoteratio $\sim \mathrm{I}$ & & $0.406^{* * *}$ \\
& & $(0.137)$ \\
& & \\
$\mathrm{N}$ & 300 & 201 \\
$\mathrm{R} 2 \_\mathrm{p}$ & 0.168 & 0.168 \\
\hline $\mathrm{N}$ & & \\
\hline
\end{tabular}

Note: Leg dummies and constant not reported. Robust standard errors in parentheses. ${ }^{* * *}$ denotes $\mathrm{p}<0.01 * * \mathrm{p}<0.05 * \mathrm{p}<0.10$ 
Figure 1A. Graphical Results of Regression Discontinuity Analysis, DC

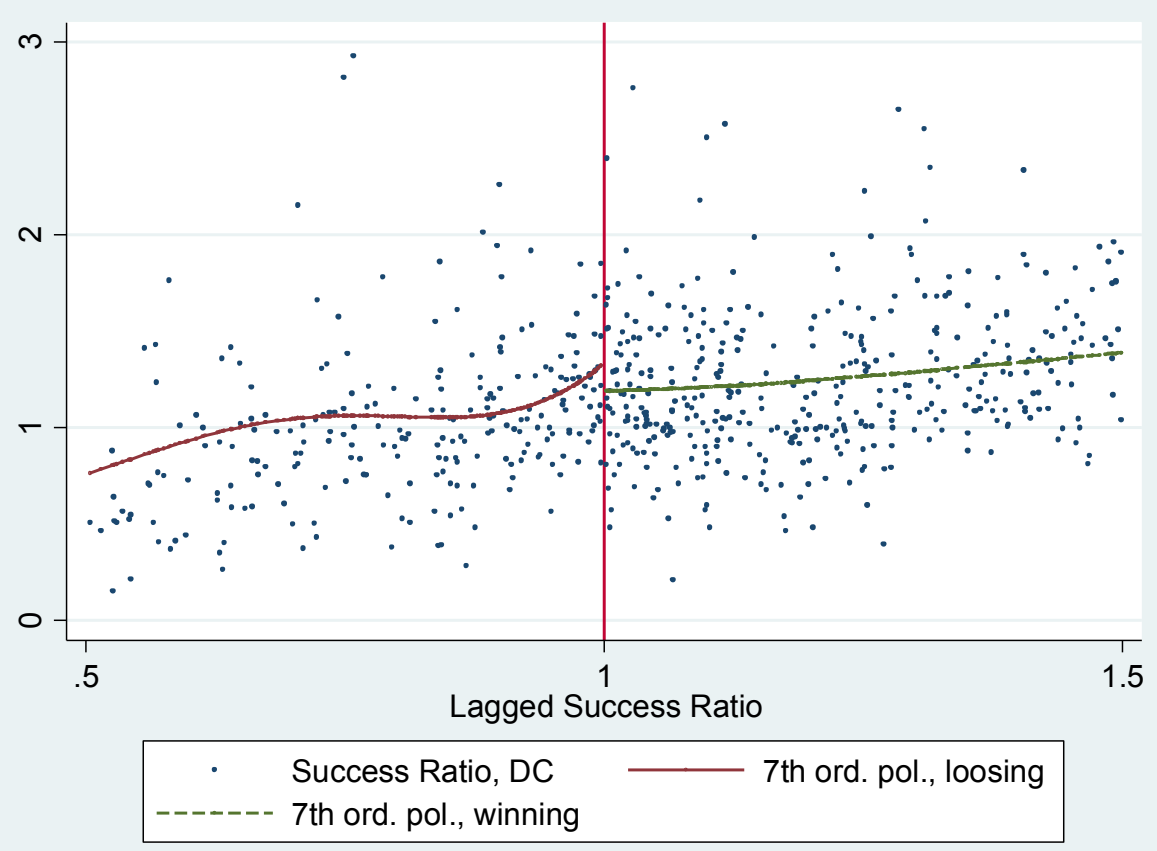

Figure 1B. Graphical Results of Regression Discontinuity Analysis, PSI

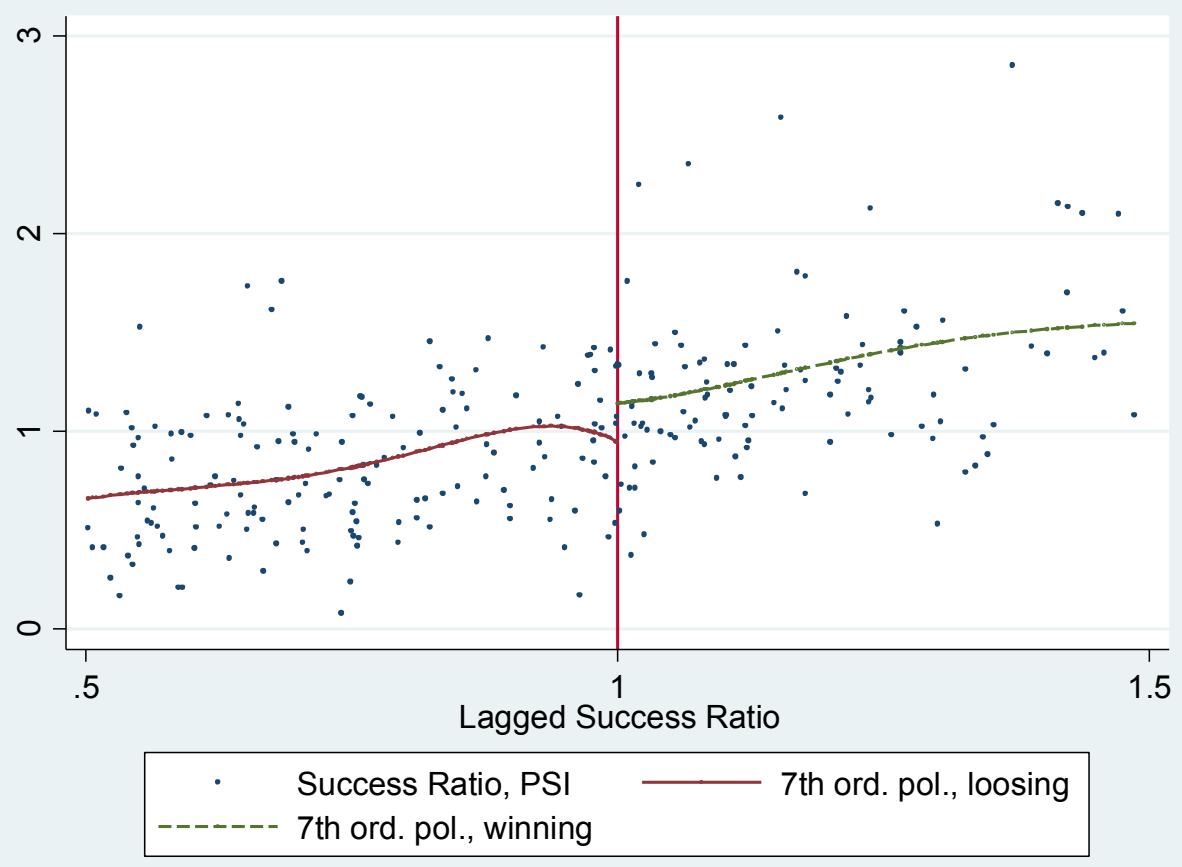


Notes: Successratio is equal to the number of preference votes received by the candidate divided by the average of the number of preference votes received by the most voted non-elected candidate and the least voted elected candidate in the same party and electoral district. 
Figure 2A: Boxplot of the variation of the ratio of preference votes to party votes over electoral districts, DC

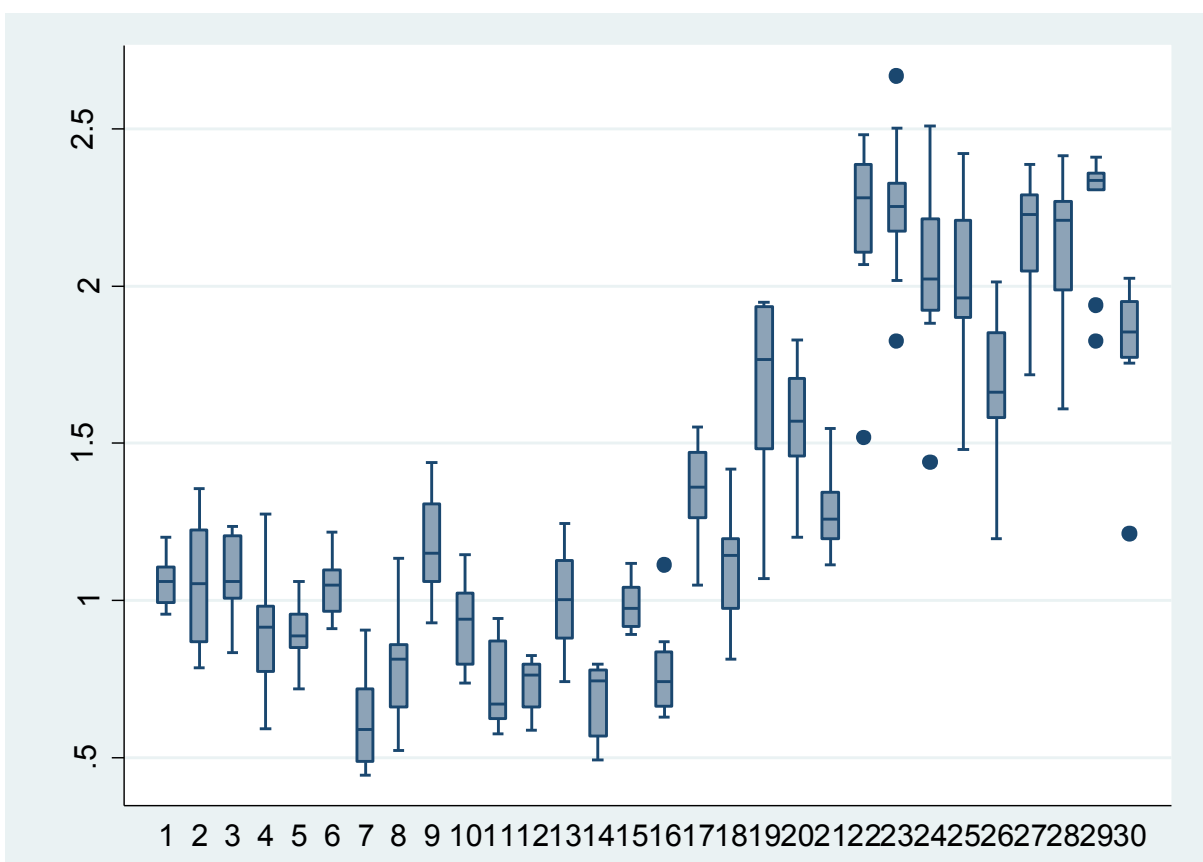

Figure 2B: Boxplot of the variation of the ratio of preference votes to party votes over electoral districts, PSI

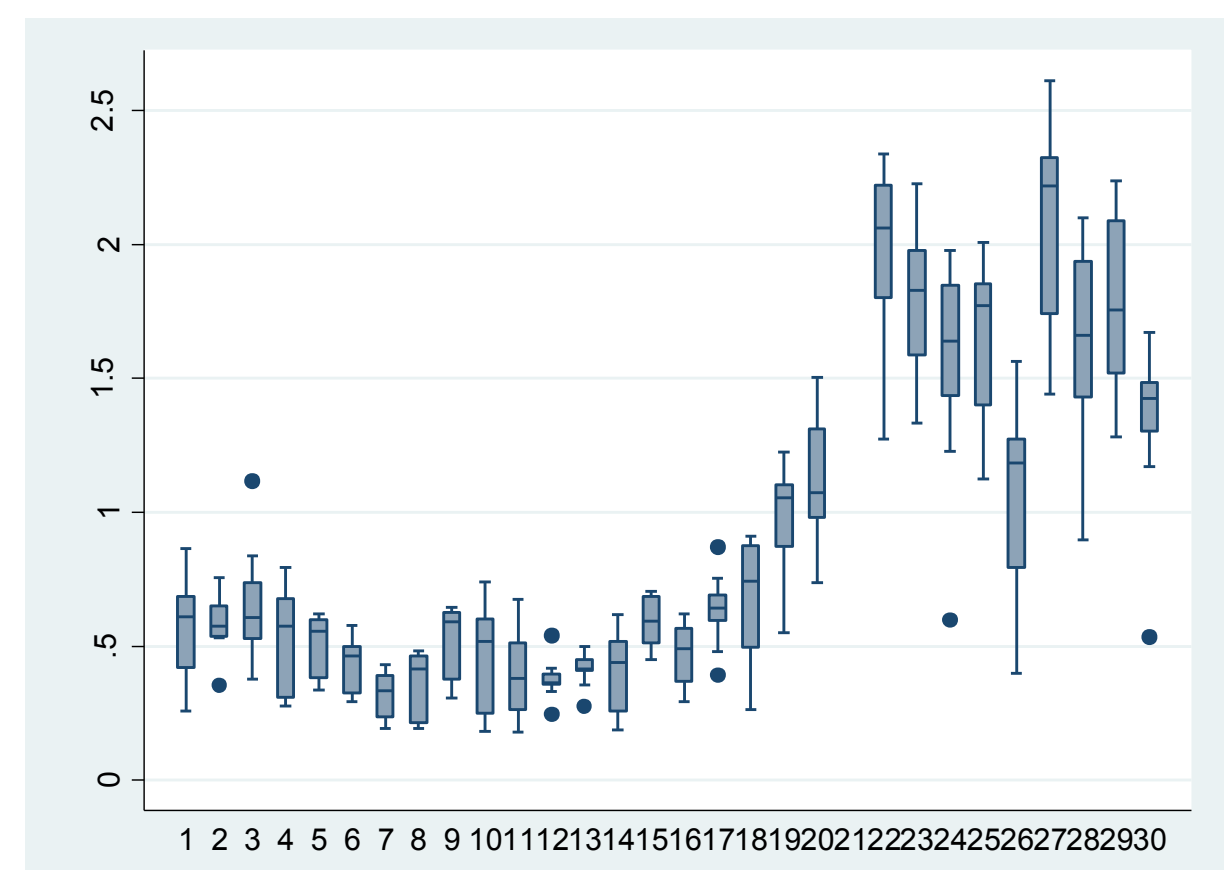




\section{Endnotes}

${ }^{1}$ This incentive did not necessarily play out the same ways for all deputies. We can imagine that there were ambitious deputies, who aimed to climb the career ladder, and less ambitious ones, who were either content with only a few terms in parliament or who understood that no matter what they did they had no chance of remaining in parliament for many terms. In the latter cases, there could have been an implicit contract between the party and its candidates, with the latter allowed by the party to become deputies while agreeing in advance to accept early parliamentary retirement in order to work for the party after only a few terms in office. Because in this period a move into parliament entailed an increase in income (especially for Communist deputies, who were less well educated than deputies from other parties) and then, for the majority of deputies, permanent party employment afterwards, serving even a few terms was typically financially attractive (Merlo et al. 2009).

${ }^{2}$ The presence of an appropriability problem may encourage types of expenditures that can be targeted to particular persons and may penalize less targetable expenditures.

${ }^{3}$ If there is a widespread belief that ruling and opposition parties engage in universalistic distributive practices, electors may even find it difficult to attribute pork barrel to the ruling coalition. In the Italian case, empirical evidence seems to contradict this (Golden and Picci 2008). Because we have complete candidate data for the DC and PSI but not for the PCI, we are not able to include the latter in the analysis. Hence, we cannot study this issue directly.

${ }^{4}$ Monitoring the performance of individual legislators in securing resources, while difficult for electors, may have been easier for the party because it would have had some leeway in aligning the effort level to the party optimum — for example, by threatening exclusion from the list in 
future elections. Also, legislators from the same district could agree to reciprocate favors in repeated interactions that made it easier to monitor each other's effort.

${ }^{5}$ In the extreme case where votes are frozen because of very strong ideological attachments, the party proper has no incentives at all and functions instead as a monopolist in a fixed portion of the political market: all competitive forces would then play out at the intra-party, intra-district level. Obviously, such a possibility is only an abstraction; demographic reasons, if nothing else, would make this unstable in practice.

${ }^{6}$ In fact, our analysis only considers 30 districts. We exclude the districts of Val d'Aosta, which due to its size elects only a single deputy, and Trieste, which existed for only part of the period under study.

${ }^{7}$ The situation changed after a referendum reduced the number of preference votes to one in the 1992 elections and then abolished preferential voting altogether with a modification of the electoral system in 1994.

${ }^{8}$ In Italy, voting was nominally mandatory during the period we study. Despite this, turnout varied across districts from about 75 to 98 percent. This variation shows that the legal obligation to vote was perceived by voters as flexible.

${ }^{9}$ Our estimates are not confined only to candidates who compete again in the same electoral district and we confine attention to candidates who have served at most one term. All deputies who served in the "Costituente" legislature - the legislature immediately following the end of World War II that drafted the Constitution of the Italian Republic - are excluded from the regression discontinuity analysis, since it is not obvious whether that special legislature should have produced any incumbency effects. If we also consider those deputies, several of whom were to serve for many legislatures in the following decades, our results are unaffected regardless of 
the incumbency status that we assign to them in the following legislature (results available on request).

${ }^{10}$ For both the DC and for the PSI, the distance at the cut-off point between fitted lines is insignificant, for any bandwidth, in a grid with intervals equal to 0.001 , starting at a 0.2 distance from the cut-off point. In the case at hand, formal testing simply confirms what is evident from a visual inspection of the data.

11 The party also decided the ordering of the names in each district. Being a "capolista" (at the top of the list) carried an electoral advantage. Unfortunately we do not have information on the order of candidates on the list.

12 Our dataset does not include information on partyexp and educ for about 3 percent of DC legislators and 18 percent of PSI legislators. Since there was no easy way of recovering that information, we also estimated the same model for both the DC and for PSI using a probit model allowing for sample selection (Van de Ven and B. M. S. Van Pragg, 1981). The results, available on request, are very similar to those that we present in Table 2.

${ }^{13}$ The estimated effects vary depending on the values of the regressors since the probit is nonlinear. The reported estimated effects have been computed corresponding to the average values of the dependent variables.

${ }^{14}$ This variable cannot be included in the model for the PSI because of collinearity problems.

${ }^{15}$ Since voters can use a maximum of three (or four in large districts) preference votes, the maximum value that this variable can take is three (or four). Some voters do not use any of their preference votes, and many use less than the maximum number allowed in their district, so that pvoteratio will typically take a value well below the maximum. 
${ }^{16}$ For both parties, a likelihood ratio test does not lead us to reject the null hypothesis of lack of overdispersion, thus justifying the use of a poisson model (instead, for example, of a negative binomial). 